\title{
Herbaspirillum hiltneri sp. nov., isolated from surface-sterilized wheat roots
}

\author{
Michael Rothballer, ${ }^{1}$ Michael Schmid, ${ }^{1}$ Ilona Klein, ${ }^{1} \dagger$ Andreas Gattinger, ${ }^{2}$ \\ Sabine Grundmann ${ }^{2}$ and Anton Hartmann ${ }^{1}$ \\ 1,2Department of Rhizosphere Biology ${ }^{1}$, Institute of Soil Ecology ${ }^{1,2}$, GSF - National Research \\ Centre for Environment and Health, Ingolstaedter Landstrasse 1, D-85764 Neuherberg, \\ Germany
}

Correspondence

Anton Hartmann

anton.hartmann@gsf.de

\begin{abstract}
The genus Herbaspirillum of the Betaproteobacteria mainly comprises diazotrophic bacteria with a potential for endophytic and systemic colonization of a variety of plants. The plant-associated bacterial isolates $\mathrm{N}^{\top}, \mathrm{N} 5$ and $\mathrm{N} 9$ were derived from surface-sterilized wheat roots. After phylogenetic analysis of $16 \mathrm{~S}$ rRNA gene sequence data the isolates could be allocated to the genus Herbaspirillum, and $99 \cdot 9 \%$ similarity to the sequence of Herbaspirillum lusitanum P6-12 ${ }^{\top}$ was found. A set of $16 \mathrm{~S}$ rRNA gene-targeted oligonucleotide probes was developed for the identification of the three novel isolates and H. Iusitanum (Hhilu446), and for the specific detection of several other Herbaspirillum species described recently. For higher phylogenetic resolution, the 23S rRNA gene sequences of all members of the genus was sequenced and used to construct a phylogenetic tree. Isolates $\mathrm{N}^{\top}{ }^{\top}, \mathrm{N} 5$ and $\mathrm{N} 9$ formed a group that was distinct from all other Herbaspirillum species. In addition, isolate $\mathrm{N}^{\top}{ }^{\top}$ and $H$. lusitanum P6-12 ${ }^{\top}$ exhibited a DNA-DNA hybridization value of only $25 \%$. The value for DNA-DNA hybridization between $\mathrm{N}^{\top}$ and other members of the genus Herbaspirillum was between 14 and $32 \%$; DNA-DNA hybridization between strain $\mathrm{N}^{\top}$ and isolates $\mathrm{N} 5$ and $\mathrm{N} 9$ produced values above $95 \%$. This places the three isolates as representatives of a novel species within the genus Herbaspirillum. A Biolog GN2 assay supported this conclusion. The major fatty acids were $\mathrm{C}_{16: 1} \omega 7 c, \mathrm{C}_{16: 0}$ and $\mathrm{C}_{18: 1} \omega 7 c$, and the DNA G + C content ranged from 60.9 to $61.5 \mathrm{~mol} \%$. Therefore these three isolates should be classified within a novel species, for which the name Herbaspirillum hiltneri sp. nov. is proposed. The type strain is $\mathrm{N3}^{\top}\left(=\mathrm{DSM} 17495^{\top}=\mathrm{LMG} 23131^{\top}\right)$.
\end{abstract}

On the basis of comparative sequence analysis of rRNAencoding genes, the genus Herbaspirillum is affiliated phylogenetically to the Betaproteobacteria (Schmid et al., 2005). The genus was first described with the species Herbaspirillum seropedicae (Baldani et al., 1986), which has been isolated from rice, maize and sorghum plants. After detailed taxonomic studies, the mildly plant-pathogenic [Pseudomonas] rubrisubalbicans was reclassified to the genus Herbaspirillum as Herbaspirillum rubrisubalbicans (Baldani et al., 1996).

tPresent address: Institute of Biochemical Plant Pathology, GSF National Research Centre for Environment and Health, Ingolstaedter Landstrasse 1, D-85764 Neuherberg, Germany.

Abbreviation: FAME, fatty acid methyl ester.

The GenBank/EMBL/DDBJ accession numbers for the 16S rRNA gene sequences of strains N3 ${ }^{\top}, N 5$ and N9 are DQ150563DQ150565, respectively, and those for the 23S rRNA gene sequences of strains $\mathrm{N}^{\top}{ }^{\top}, \mathrm{N} 5$ and $\mathrm{N9}$ are DQ150552-DQ150554.

A similarity matrix based on $16 \mathrm{~S}$ and $23 \mathrm{~S}$ rRNA gene sequences of Herbaspirillum species is available as supplementary material in IJSEM Online.
Another species of this genus, Herbaspirillum frisingense, was isolated from the C4-fibre plants Miscanthus spp., Spartina spectinata and Pennisetum purpureum by Kirchhof et al. (2001). From root nodules of garden beans (Phaseolus vulgaris), several strains representing one distinct species were isolated and described as Herbaspirillum lusitanum (Valverde et al., 2003). These root-colonizing Herbaspirillum species were detected not only on the surface of the root, but also as intra- and intercellular colonizers in the root interior (Olivares et al., 1997). These bacteria seem to prefer plants of the family Gramineae as hosts (Kirchhof et al., 2001), but they are also found on other plant species (Baldani et al., 1996). According to Döbereiner et al. (1993), the close association of endophytically colonizing herbaspirilli results in an additional supply of bacterially fixed nitrogen for the host plant. Experimental evidence for this thesis was provided by Elbeltagy et al. (2001) using rice (Oryza officinalis) inoculated with Herbaspirillum sp. strain B501.

The organisms listed so far all display the ability to fix atmospheric nitrogen, but, according to the latest taxonomic data, this can no longer be considered a common feature 
within the genus Herbaspirillum. In Korea, a 4-chlorophenoldegrading strain was isolated from river sediments near an industrial plant (Bae et al., 1996). Because of its morphological and physiological attributes, this isolate was first thought to belong to the species Comamonas testosteroni (Bae et al., 1996), but further phylogenetic analyses based on $16 \mathrm{~S}$ rRNA gene sequences, as well as DNA-DNA hybridization experiments, indicated that this classification was incorrect; the name Herbaspirillum chlorophenolicum was proposed by Im et al. (2004) for this non-plant-associated strain. Ding \& Yokota (2004) discovered a novel species in well water, and described it as Herbaspirillum putei; in the same study, the authors proposed the transfer of [Aquaspirillum] autotrophicum and [Pseudomonas] huttiensis to the genus Herbaspirillum as Herbaspirillum autotrophicum and Herbaspirillum huttiense. All three isolates were unable to fix nitrogen under laboratory conditions; only in $H$. putei was the nifH gene required for nitrogen fixation detected by PCR-based methods.

In this publication, we characterize the three isolates $\mathrm{N} 3^{\mathrm{T}}$, $\mathrm{N} 5$ and $\mathrm{N} 9$, which originated from surface-sterilized wheat roots (Triticum aestivum). On the basis of $16 \mathrm{~S}$ and $23 \mathrm{~S}$ rRNA gene sequence data, as well as DNA-DNA hybridization results and phenotypic features, these isolates belong to a novel species within the genus Herbaspirillum.

Isolates $\mathrm{N} 3^{\mathrm{T}}, \mathrm{N} 5$ and $\mathrm{N} 9$ were derived from 4- to 8-week-old wheat plants (T. aestivum var. Naxos) grown in agricultural soil from Neumarkt (Oberpfalz, Germany). Surface sterilization was carried out with chloramine $\mathrm{T}(1 \% \mathrm{w} / \mathrm{v})$ for $10 \mathrm{~min}$. After surface sterilization, roots were washed three times with $1 \times \mathrm{PBS}$, crushed and then plated on NB agar

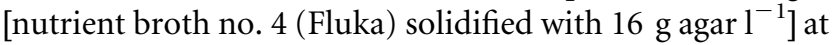
appropriate dilutions to obtain single colonies. Colonies were picked and singled out on new plates. With the exception of H. lusitanum P6-12 ${ }^{\mathrm{T}}$ (a gift from J. Igual, Instituto de Recursos Naturales y Agrobiología, Salamanca, Spain), reference strains of Herbaspirillum were obtained from the Deutsche Sammlung von Mikroorganismen und Zellkulturen (DSMZ) (Braunschweig, Germany) or the IAM Culture Collection (Institute of Applied Microbiology, The University of Tokyo, Japan). All Herbaspirillum strains were grown at $30^{\circ} \mathrm{C}$ on NB medium. For nitrogen-free microaerobic growth conditions, semi-solid JNFb medium was used as described by Döbereiner (1995).

Oxidase activity was determined from the oxidation of $1 \%$ $N, N$-dimethyl- $p$-phenylenediamine hemioxalate. The presence of catalase activity was demonstrated by bubble formation in a $3 \%(\mathrm{v} / \mathrm{v}) \mathrm{H}_{2} \mathrm{O}_{2}$ solution. Metabolism of various substrates was tested in at least three replicates with Biolog GN2 Microplates according to the protocol provided by the manufacturer. Temperature and $\mathrm{pH}$ growth optima were determined in NB liquid medium (nutrient broth no. 4) after $16 \mathrm{~h}$ growth at $30^{\circ} \mathrm{C}$. Culture medium $(5 \mathrm{ml})$ was inoculated with $10 \mu \mathrm{l}$ preculture grown overnight. After incubation, the cell density was measured photometrically at $436 \mathrm{~nm}$. The $\mathrm{pH}$ was adjusted by adding $0.05 \mathrm{M}$ MES or MOPS buffer (Sigma-Aldrich).

Chromosomal DNA was isolated with a NucleoSpinTissue kit (Macherey Nagel). A PCR was performed in a Thermocycler Primus 25 (MWG-Biotech) in a total volume of $50 \mu \mathrm{l}$ per reaction, according to standard protocols. The annealing temperature was $50^{\circ} \mathrm{C}$ for all primers. The universal $16 \mathrm{~S}$ primer $616-\mathrm{V}$ (5'-AGAGTTTGATYMTGGCTCAG-3') and 630-R (5'-CAKAAAGGAGGTGATCC$\left.3^{\prime}\right)$, as well as the universal $23 \mathrm{~S}$ primers $118-\mathrm{V}\left(5^{\prime}\right.$-CCGAATGGGGRAACCC-3') and 985-R (5' -CCGGTCCTCTCGTACT- $\left.3^{\prime}\right)$ were used for the PCR and sequencing. Additionally, the internal $23 \mathrm{~S}$ primer $1019-\mathrm{V}$ (5'-TAGCTGGTTCTYYCCGAA-3') was used for sequencing only. Amplified DNA fragments were cloned with the TOPO TA cloning kit (Invitrogen). Clones were sequenced using the Big Dye Terminator labelling kit (Applera) with an ABI PRISM 3730 DNA analyser (Applied Biosystems). For phylogenetic analyses, the 16S and 23S rRNA gene sequences obtained were aligned with the FastAligner version 1.03 tool implemented in the ARB software package (Strunk \& Ludwig, 1997; Ludwig et al., 2004). Phylogenetic tree construction was performed by using the maximum-likelihood (Olsen et al., 1994), neighbour-joining (Saitou \& Nei, 1987) and maximum-parsimony (Felsenstein, 1993) methods.

For fluorescence in-situ hybridization (FISH), $1 \mathrm{ml}$ pure overnight culture was fixed with $4 \%$ paraformaldehyde for at least $1 \mathrm{~h}$ at $4{ }^{\circ} \mathrm{C}$ (Amann et al., 1990). Hybridization with fluorochrome (fluorescein, Cy3)-labelled oligonucleotide probes was performed according to the protocols described by Manz et al. (1992) and Amann et al. (1992). New genusand species-specific oligonucleotide probes based on $16 \mathrm{~S}$ rRNA gene sequence data were created using the probedesign and probe-match tools of the ARB software package (Strunk \& Ludwig, 1997; Ludwig et al., 2004). Hybridization conditions for the in-situ application of the newly developed probes had to be optimized by gradually increasing the formamide concentration in the hybridization buffer, as described by Manz et al. (1992). To determine the correct stringency conditions for hybridization, non-target bacterial species with only one or two mismatches in the target sequence were included in each hybridization.

Light-microscopic observation of cell morphology and size, as well as wavelength-specific detection of FISH-labelled cells, was performed with an Axioplan 2 epifluorescence microscope (Zeiss) equipped with filter sets 01,09 and 15 .

For scanning electron microscopy, cells were grown overnight in NB medium and then harvested from $1 \mathrm{ml}$ cell suspension by centrifugation at $5000 \mathrm{~g}$ for $5 \mathrm{~min}$. The cells were washed twice with $1 \times$ PBS and fixed with $2 \mathrm{ml} 1 \%$ glutaraldehyde in PBS ( $\mathrm{pH} 7 \cdot 4$ ) overnight at $4{ }^{\circ} \mathrm{C}$. The fixed cells were dehydrated through a series of ethanol solutions at increasing concentrations (50, 70, 80, 95 and $100 \%$ ethanol). Ethanol was replaced with liquid $\mathrm{CO}_{2}$, and the samples were dried in a critical-point dryer. Cells were 
sputter-coated with platinum and examined in a scanning electron microscope (JSM 6300F; JEOL).

PCR amplification of the nifH and nifD genes was carried out by using bacterial genomic DNA as a template. Various primers and reaction conditions were used as described by Zehr \& McReynolds (1989), Kloos et al. (1995), Stoltzfus et al. (1997) and Kirchhof et al. (2001).

For DNA-DNA hybridizations, about $3 \mathrm{~g}$ cell material was produced for each isolate by centrifuging a 21 overnight culture for $25 \mathrm{~min}$ at $5000 \mathrm{~g}$. After two washing steps with

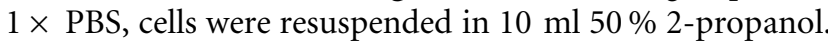
All further steps were carried out by the DSMZ according to the protocols of Cashion et al. (1977) and De Ley et al. (1970), with the modifications described by Huß et al. (1983) and Escara \& Hutton (1980). Renaturation rates were calculated with the program TRANSFER.BAS of Jahnke (1992).

The DNA G + C contents of the isolates were determined by the method described by Mesbah \& Whitman (1989) with an HPLC system (LaChrom; Merck/Hitachi) using an L7400 UV detector.

The analysis of cellular fatty acids was performed according to a slightly modified procedure described by Gattinger et al. (2002). Briefly, cells grown overnight on NB medium were washed twice with $1 \times$ PBS. Lipids were extracted from these fresh cells, according to the Bligh-Dyer method, using phosphate buffer $(0 \cdot 05 \mathrm{M}, \mathrm{pH} 7 \cdot 4)$, methanol and chloroform as extraction solvents. The resulting lipid material was subjected to mild alkaline methanolysis (Zelles \& Bai, 1993) to yield fatty acid methyl esters (FAME). One aliquot of the FAME sample was derivatized with 1-trimethylsilyl imidazole (TMSI) and the other was derivatized with dimethyl disulfide (DMDS) (Zelles \& Bai, 1993) to generate analytes suitable for GC and the localization of functional groups in the FAME molecule. GC/MS was performed with a Hewlett Packard 5971A mass selective detector combined with a 5890 series II GC system, equipped with an HP 5 capillary column (50 m length, $0 \cdot 25 \mathrm{~mm}$ internal diameter; coated with a cross-linked $5 \%$ phenylmethyl rubber phase with a film thickness of $0.3 \mu \mathrm{m}$ ), with helium as the carrier gas, at operating conditions as described elsewhere (Zelles \& Bai, 1993). The identification and quantification of individual components were achieved using chromatography software (HP ChemStation; SOLVIT) and comparison with a FAME standard mixture. Under these GC conditions FAMEs containing 10 or more carbon atoms could be determined.

The three isolates $\mathrm{N} 3^{\mathrm{T}}$, N5 and $\mathrm{N} 9$ were Gram-negative, motile, slightly curved rods that formed circular, smooth, opaque and convex colonies after overnight growth on NB agar at $30^{\circ} \mathrm{C}$. They were positive for oxidase and catalase and showed optimal growth at temperatures between 26 and $34{ }^{\circ} \mathrm{C}$ and at $\mathrm{pH}$ values between 6 and 8 . For examination of cell size and flagella, scanning electron micrographs were prepared (Fig. 1a, b). Up to three unipolar flagella could be detected, but most cells had two flagella. The size of single cells ranged between 1.6 and $2 \cdot 0 \mu \mathrm{m}$ in length and between 0.5 and $0.6 \mu \mathrm{m}$ in diameter. The isolates were unable to grow on semi-solid, nitrogen-free JNFb medium (Kirchhof et al., 2001) and detection of nifD and nifH genes was not possible with PCR-based methods using various specific primers. According to these results, the isolates do not possess the ability to fix atmospheric nitrogen. As the isolates were derived from surface-sterilized wheat roots, they seem to be very closely associated with the plant host and perhaps even possess the potential for endophytic colonization.

All three isolates showed the same characteristic carbonsource utilization in the Biolog GN2 test, but differed clearly from the other Herbaspirillum species. Numerous sugars, as well as fatty acids and some amino acids and alcohols, were readily metabolized. Disaccharides and trisaccharides could not be used as carbon sources. The ability to use L-phenylalanine as a carbon source was characteristic of isolates $\mathrm{N}^{\mathrm{T}}$, N5 and N9; the other Herbaspirillum species did not have this capacity. Further details are listed in Table 1 . The major fatty acids detected were $\mathrm{C}_{16: 1} \omega 7 c, \mathrm{C}_{16: 0}$ and $\mathrm{C}_{18: 1} \omega 7 c$; smaller proportions of $\mathrm{C}_{17: 0}$ cyclo and $\mathrm{C}_{18: 0}$ were also found. All of the other fatty acids detected were present at $<1 \mathrm{~mol} \%$ (Table 2). Similar results were obtained for other Herbaspirillum species, which showed the same dominant fatty acids with only slight differences in mole ratios (Ding \& Yokota, 2004).
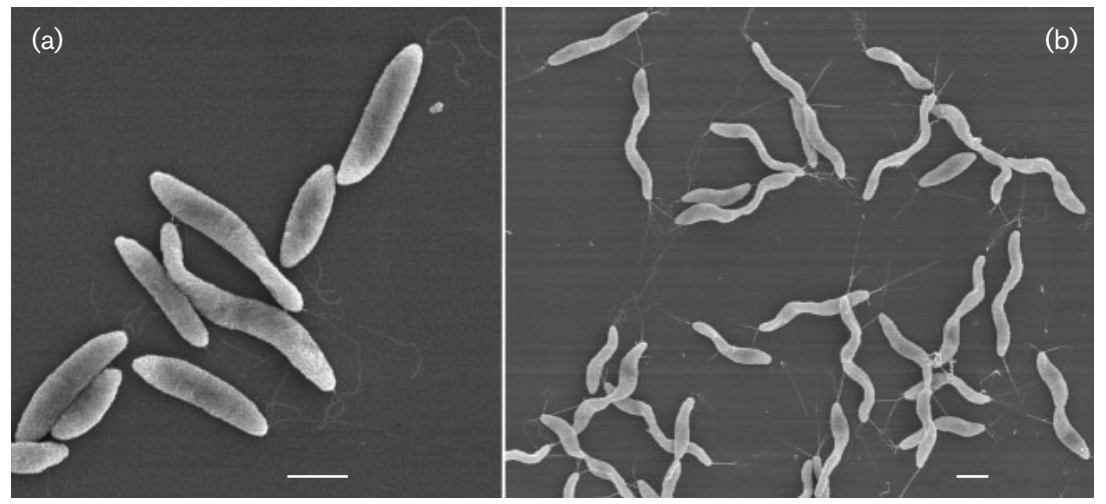

Fig. 1. Scanning electron micrographs of isolate $\mathrm{N}^{\top}$. In (a), several single cells with polar flagella can be seen. The two elongated cells in the middle of the picture were just about to divide. In (b), virtually all cells shown are dividing. One, two or three polar flagella are clearly visible on every cell. Bars, $1 \mu \mathrm{m}$. 
Table 1. Utilization of different carbon sources in Biolog GN2 microplates by members of the genus Herbaspirillum

Strains: 1, H. putei IAM $15032^{\mathrm{T}}$; 2, H. huttiense DSM $10281^{\mathrm{T}} ; 3$, H. autotrophicum DSM $732^{\mathrm{T}}$; 4, H. chlorophenolicum IAM 15024 ${ }^{\mathrm{T}}$; 5, H. frisingense GSF30 ${ }^{\mathrm{T}}$; 6, H. rubrisubalbicans DSM 9440 $;$; , H. seropedicae DSM $6445^{\mathrm{T}}$; 8, H. lusitanum P6-12 ${ }^{\mathrm{T}}$; 9 , strains $\mathrm{N}^{\mathrm{T}}$, N5 and N9 (identical results were obtained for the three strains). +, Positive; $(+)$, ambiguous; - , negative. All strains were positive for utilization of malic acid, methyl pyruvate, succinic acid monomethyl ester, acetic acid, cis-aconitic acid, citric acid, formic acid, D-gluconic acid, $\beta$-hydroxybutyric acid, $\alpha$-ketobutyric acid, $\alpha$-ketoglutaric acid, DL-lactic acid, propionic acid, succinic acid, bromosuccinic acid, succinamic acid, D-alanine, L-asparagine, L-aspartic acid, L-glutamic acid, L-proline and L-pyroglutamic acid. All strains were negative for water (negative control), $\alpha$-cyclodextrin, $N$-acetyl-D-galactosamine, D-cellobiose, gentiobiose, $\alpha$-D-lactose, lactulose, maltose, D-melibiose, D-raffinose, sucrose, turanose, $\alpha$-ketovaleric acid, sebacic acid, glycyl L-aspartic acid, glycyl L-glutamic acid, L-histidine, hydroxy-L-proline, L-ornithine, DL-carnitine, urocanic acid, inosine, uridine, thymidine, phenylethylamine, putrescine, 2,3-butanediol and glucose 1-phosphate.

\begin{tabular}{|c|c|c|c|c|c|c|c|c|c|}
\hline Carbon source & 1 & 2 & 3 & 4 & 5 & 6 & 7 & 8 & 9 \\
\hline Dextrin & - & - & - & - & - & + & - & - & - \\
\hline Glycogen & - & + & + & + & + & + & + & + & + \\
\hline Tween 40 & - & + & + & + & + & + & + & + & + \\
\hline Tween 80 & - & + & + & + & + & + & + & + & + \\
\hline$N$-Acetyl-D-glucosamine & - & - & - & + & + & - & + & + & + \\
\hline Adonitol & + & + & - & - & + & + & + & + & - \\
\hline L-Arabinose & + & + & - & + & + & + & + & + & + \\
\hline D-Arabitol & + & + & - & + & + & + & + & + & + \\
\hline i-Erythritol & $(+)$ & + & - & - & - & + & - & - & - \\
\hline D-Fructose & - & - & - & - & + & + & + & + & - \\
\hline L-Fucose & $(+)$ & + & - & + & + & + & + & + & + \\
\hline D-Galactose & + & + & - & + & + & + & + & + & + \\
\hline$\alpha$-D-Glucose & + & + & - & + & + & + & + & + & + \\
\hline myo-Inositol & - & - & - & - & - & - & + & - & - \\
\hline D-Mannitol & + & + & - & + & + & + & + & + & + \\
\hline D-Mannose & - & - & - & - & + & + & + & - & - \\
\hline Methyl $\beta$-D-glucoside & - & - & - & - & - & + & - & - & - \\
\hline D-Psicose & - & - & - & + & + & - & + & + & + \\
\hline L-Rhamnose & - & - & - & - & - & - & + & + & - \\
\hline D-Sorbitol & + & + & - & + & + & + & + & - & + \\
\hline D-Trehalose & - & - & - & - & - & + & - & - & - \\
\hline Xylitol & + & + & - & - & + & + & + & - & + \\
\hline D-Galactonic acid lactone & - & - & + & + & + & + & + & + & + \\
\hline D-Galacturonic acid & - & + & - & - & + & + & + & + & + \\
\hline D-Glucosaminic acid & - & - & - & + & + & - & - & + & + \\
\hline D-Glucuronic acid & - & + & - & - & - & + & + & + & + \\
\hline$\alpha$-Hydroxybutyric acid & - & + & + & + & + & + & + & + & + \\
\hline$\gamma$-Hydroxybutyric acid & - & - & + & - & - & - & - & - & - \\
\hline p-Hydroxyphenylacetic acid & + & - & + & - & + & + & + & - & - \\
\hline Itaconic acid & $(+)$ & - & + & + & + & + & + & + & + \\
\hline Malonic acid & - & - & + & - & + & - & - & + & + \\
\hline Quinic acid & + & + & - & - & - & + & + & - & - \\
\hline D-Saccharic acid & + & + & - & + & + & + & + & + & + \\
\hline Glucuronamide & - & - & - & - & - & + & + & + & + \\
\hline L-Alaninamide & - & - & - & + & - & + & - & - & + \\
\hline L-Alanine & - & - & + & + & + & + & - & + & + \\
\hline L-Alanyl glycine & - & + & - & - & + & - & - & - & - \\
\hline L-Leucine & - & - & - & - & + & + & - & - & - \\
\hline L-Phenylalanine & - & - & - & - & - & - & - & - & + \\
\hline D-Serine & - & - & - & - & + & - & - & - & - \\
\hline L-Serine & - & - & - & - & + & - & - & - & - \\
\hline L-Threonine & - & + & - & + & + & + & - & - & + \\
\hline$\gamma$-Aminobutyric acid & $(+)$ & + & - & + & + & + & + & - & - \\
\hline 2-Aminoethanol & + & + & - & - & + & + & + & - & - \\
\hline Glycerol & + & + & - & - & + & + & + & + & + \\
\hline DL- $\alpha$-Glycerol phosphate & - & - & - & - & + & - & + & + & - \\
\hline Glucose 6-phosphate & - & - & - & - & - & - & + & - & - \\
\hline
\end{tabular}


Table 2. Fatty acid profiles of isolates $N 3^{\top}, N 5$ and $N 9$

Mean values of two measurements \pm range of values are given in mol\%. FAMEs $\mathrm{C}_{12: 0}, \mathrm{C}_{15: 0}$ iso, $\mathrm{C}_{24: 0}, \mathrm{C}_{10: 0} 2-\mathrm{OH}, \mathrm{C}_{10: 0} 3-\mathrm{OH}$, $\mathrm{C}_{12: 0} 2-\mathrm{OH}, \mathrm{C}_{12: 0} 3-\mathrm{OH}, \mathrm{C}_{12: 0} 11-\mathrm{OH}, \mathrm{C}_{13: 1} 12-\mathrm{OH}$ and $\mathrm{C}_{17: 1}$ $17-\mathrm{OH}$ could not be detected in any of the isolates. ND, Not detectable; tr, trace amount $(<0 \cdot 1 \%)$.

\begin{tabular}{|c|c|c|c|}
\hline FAME & $N 3^{T}$ & N5 & N9 \\
\hline $\mathrm{C}_{14: 0}$ & $0 \cdot 5 \pm 0 \cdot 3$ & $0 \cdot 3 \pm 0 \cdot 1$ & $0 \cdot 2 \pm 0 \cdot 0$ \\
\hline $\mathrm{C}_{15: 0}$ anteiso & $0 \cdot 1 \pm 0 \cdot 0$ & ND & ND \\
\hline $\mathrm{C}_{15: 0}$ & $0 \cdot 2 \pm 0 \cdot 1$ & $0 \cdot 1 \pm 0 \cdot 0$ & $0 \cdot 1 \pm 0 \cdot 0$ \\
\hline $\mathrm{C}_{16: 1} \omega 7 c$ & $44 \cdot 5 \pm 1 \cdot 8$ & $44 \cdot 9 \pm 0 \cdot 6$ & $46 \cdot 8 \pm 2 \cdot 8$ \\
\hline $\mathrm{C}_{16: 1} \omega 7 t$ & $0 \cdot 2 \pm 0 \cdot 1$ & $0 \cdot 3 \pm 0 \cdot 0$ & ND \\
\hline $\mathrm{C}_{16: 1} \omega 5$ & $0 \cdot 1 \pm 0 \cdot 0$ & $0 \cdot 1 \pm 0 \cdot 0$ & $0 \cdot 1 \pm 0 \cdot 0$ \\
\hline $\mathrm{C}_{16: 0}$ & $26 \cdot 4 \pm 2 \cdot 5$ & $24 \cdot 6 \pm 0 \cdot 4$ & $26 \cdot 3 \pm 0 \cdot 7$ \\
\hline $\mathrm{C}_{17: 1} \omega 7$ & $0 \cdot 1 \pm 0 \cdot 0$ & $0 \cdot 1 \pm 0 \cdot 0$ & $0 \cdot 1 \pm 0 \cdot 0$ \\
\hline $\mathrm{C}_{17: 0}$ cyclo & $4 \cdot 0 \pm 0 \cdot 9$ & $6 \cdot 0 \pm 0 \cdot 9$ & $3 \cdot 8 \pm 5 \cdot 0$ \\
\hline $\mathrm{C}_{17: 0}$ & $0 \cdot 1 \pm 0 \cdot 1$ & $0 \cdot 1 \pm 0 \cdot 0$ & $0 \cdot 1 \pm 0 \cdot 1$ \\
\hline $\mathrm{C}_{18: 1} \omega 9$ & $0 \cdot 4 \pm 0 \cdot 1$ & $0 \cdot 2 \pm 0 \cdot 1$ & $0 \cdot 2 \pm 0 \cdot 0$ \\
\hline $\mathrm{C}_{18: 1} \omega 7 c$ & $18 \cdot 2 \pm 4 \cdot 9$ & $20 \cdot 3 \pm 0 \cdot 4$ & $19 \cdot 4 \pm 1 \cdot 1$ \\
\hline $\mathrm{C}_{18: 1} \omega 7 t$ & $0 \cdot 1 \pm 0 \cdot 0$ & $0 \cdot 1 \pm 0 \cdot 0$ & $0 \cdot 1 \pm 0 \cdot 0$ \\
\hline $\mathrm{C}_{18: 0}$ & $2 \cdot 7 \pm 0 \cdot 3$ & $1 \cdot 6 \pm 0 \cdot 1$ & $2 \cdot 1 \pm 0 \cdot 6$ \\
\hline $\mathrm{C}_{19: 0}$ cyclo & $0 \cdot 1 \pm 0 \cdot 1$ & $0 \cdot 1 \pm 0 \cdot 0$ & $0 \cdot 1 \pm 0 \cdot 0$ \\
\hline $\mathrm{C}_{20: 0}$ & $0 \cdot 1 \pm 0 \cdot 1$ & $0 \cdot 1 \pm 0 \cdot 0$ & $0 \cdot 1 \pm 0 \cdot 0$ \\
\hline$C_{22: 0}$ & $0 \cdot 1 \pm 0 \cdot 1$ & $0 \cdot 1 \pm 0 \cdot 0$ & $0 \cdot 1 \pm 0 \cdot 0$ \\
\hline $\mathrm{C}_{10: 1} 9-\mathrm{OH}$ & $0 \cdot 1 \pm 0 \cdot 0$ & ND & ND \\
\hline $\mathrm{C}_{11: 1} 11-\mathrm{OH}$ & $0 \cdot 1 \pm 0 \cdot 0$ & ND & ND \\
\hline $\mathrm{C}_{12: 1} 11-\mathrm{OH}$ & $0 \cdot 1 \pm 0 \cdot 0$ & $0 \cdot 1 \pm 0 \cdot 0$ & ND \\
\hline $\mathrm{C}_{14: 0} 3-\mathrm{OH}$ & $\operatorname{tr}$ & $\operatorname{tr}$ & \\
\hline $\mathrm{C}_{14: 0} 2-\mathrm{OH}$ & $\operatorname{tr}$ & $\operatorname{tr}$ & $\operatorname{tr}$ \\
\hline $\mathrm{C}_{13: 1} 13-\mathrm{OH}$ & $0 \cdot 1 \pm 0 \cdot 0$ & $\mathrm{ND}$ & $\operatorname{tr}$ \\
\hline $\mathrm{C}_{16: 0}$ methoxy & $0 \cdot 8 \pm 0 \cdot 4$ & $0 \cdot 3 \pm 0 \cdot 0$ & $0 \cdot 2 \pm 0 \cdot 1$ \\
\hline $\mathrm{C}_{16: 0} 3-\mathrm{OH}$ & $\operatorname{tr}$ & $\operatorname{tr}$ & $\operatorname{tr}$ \\
\hline $\mathrm{C}_{16: 0} 2-\mathrm{OH}$ & $\operatorname{tr}$ & $\operatorname{tr}$ & $\operatorname{tr}$ \\
\hline $\mathrm{C}_{16: 1} 15-\mathrm{OH}$ & $0 \cdot 7 \pm 0 \cdot 3$ & $0 \cdot 1 \pm 0 \cdot 0$ & ND \\
\hline
\end{tabular}

${ }^{*}$ Binding position could not be determined with this method.

After sequencing of the almost complete 16S rRNA genes, the three isolates were taxonomically allocated by means of phylogenetic analysis. They had identical $16 \mathrm{~S}$ rRNA gene sequences and showed $97 \%$ or greater sequence similarity to the known Herbaspirillum species (see Supplementary Table S1 available in IJSEM Online). As a value of $95 \%$ or more is considered to be a criterion for affiliation to the same genus (Ludwig et al., 1998), these results provided evidence that the three isolates belong to the genus Herbaspirillum. The highest sequence similarity $(99.9 \%)$ was detected with $H$. lusitanum P6-12 ${ }^{\mathrm{T}}$, which was an indication that $\mathrm{N} 3^{\mathrm{T}}, \mathrm{N} 5$ and $\mathrm{N} 9$ were representatives of this species. However, all species of the genus Herbaspirillum exhibit a high degree of $16 \mathrm{~S}$ rRNA gene sequence similarity, which ranges between $97 \cdot 0$ and $99 \cdot 9 \%$ (Supplementary Table S1). This is characteristic of species whose divergence has begun relatively recently and which are therefore hard to differentiate by 16S rRNA gene sequence-based methods (Fox et al., 1992). In this case, analysis of $16 \mathrm{~S}$ rRNA gene sequences cannot provide sufficient evidence for species affiliation (Rossello-Mora \& Amann, 2001).

In order to clarify the species affiliation of the novel strains, $2.5 \mathrm{~kb}$ fragments of the $23 \mathrm{~S}$ rRNA genes of all the Herbaspirillum species were sequenced and phylogenetically analysed. The three isolates showed similarities of $99 \cdot 8-$ $99.9 \%$ with respect to each other (see Supplementary Table S1). The sequence similarities between $H$. lusitanum P6- $12^{\mathrm{T}}$ and the three isolates were $98 \cdot 9-99 \cdot 0 \%$, while the similarities within the genus ranged from $96 \cdot 3$ to $99 \cdot 7 \%$. Since there are not as many $23 \mathrm{~S}$ rRNA gene sequences available as there are for the $16 \mathrm{~S}$ rRNA gene, the threshold values for species and genus level are not so clearly defined using the former (Rossello-Mora \& Amann, 2001). However, as the type strains of $H$. huttiense and $H$. putei show $23 \mathrm{~S}$ rRNA gene sequence similarity of $99 \cdot 7 \%$, which is higher than the similarity between our isolates and $H$. lusitanum P6- $12^{\mathrm{T}}$, these results provide a first indication that $\mathrm{N} 3^{\mathrm{T}}, \mathrm{N} 5$ and $\mathrm{N} 9$ represent a distinct species within the genus Herbaspirillum. With the higher resolution of the 23S rRNA gene sequence data, the construction of a phylogenetic tree became possible (Fig. 2): it showed two distinct clusters of Herbaspirillum species. One cluster consisted of the type strains of $H$. seropedicae, $H$. rubrisubalbicans, $H$. huttiense, $H$. putei, $H$. frisingense and $H$. chlorophenolicum, while the other contained the type strains of $H$. autotrophicum and H. lusitanum and isolates $\mathrm{N} 3^{\mathrm{T}}, \mathrm{N} 5$ and $\mathrm{N} 9$. The closely related genus Collimonas is difficult to separate from the genus Herbaspirillum by phylogenetic analysis based on $16 \mathrm{~S}$ rRNA or $23 \mathrm{~S}$ rRNA gene sequence data, but it is clearly distinct when biochemical and physiological characteristics are considered (de Boer et al., 2004).

DNA-DNA hybridization was used to compare isolate $\mathrm{N}^{\mathrm{T}}$ with the type strains of all other Herbaspirillum species and with isolates N5 and N9. With this technique, the values for hybridization of isolate $\mathrm{N} 3^{\mathrm{T}}$ with $\mathrm{N} 5$ and with $\mathrm{N} 9$ were found to be 95 and $100 \%$, respectively, which clearly indicates the affiliation of the three isolates to one species. For $\mathrm{N}^{\mathrm{T}}$ and H. lusitanum $\mathrm{P} 6-12^{\mathrm{T}}$, values of only $25 \%$ could be detected. This is far below the threshold of $70 \%$ that is typically reached in DNA-DNA hybridizations between strains of the same species (Wayne et al., 1987). Although this guideline value cannot be considered as absolute and is extended to $50 \%$ in some exceptional cases (Stackebrandt \& Goebel, 1994), the affiliation of isolate $\mathrm{N} 3^{\mathrm{T}}$ to the species $H$. lusitanum could be ruled out according to these results. A DNA-DNA hybridization value as low as this is unusual in the context of a $16 \mathrm{~S}$ rRNA gene sequence similarity of almost $100 \%$, but there are several comparable examples in the literature. Fox et al. (1992) detected similarly low DNADNA hybridization values when comparing several Bacillus globisporus and Bacillus psychrophilus strains, although a $99 \cdot 5 \% 16 \mathrm{~S}$ rRNA gene sequence similarity, as well as various phenotypic traits, pointed towards an affiliation of the strains to the same species. Jaspers \& Overmann (2004) 


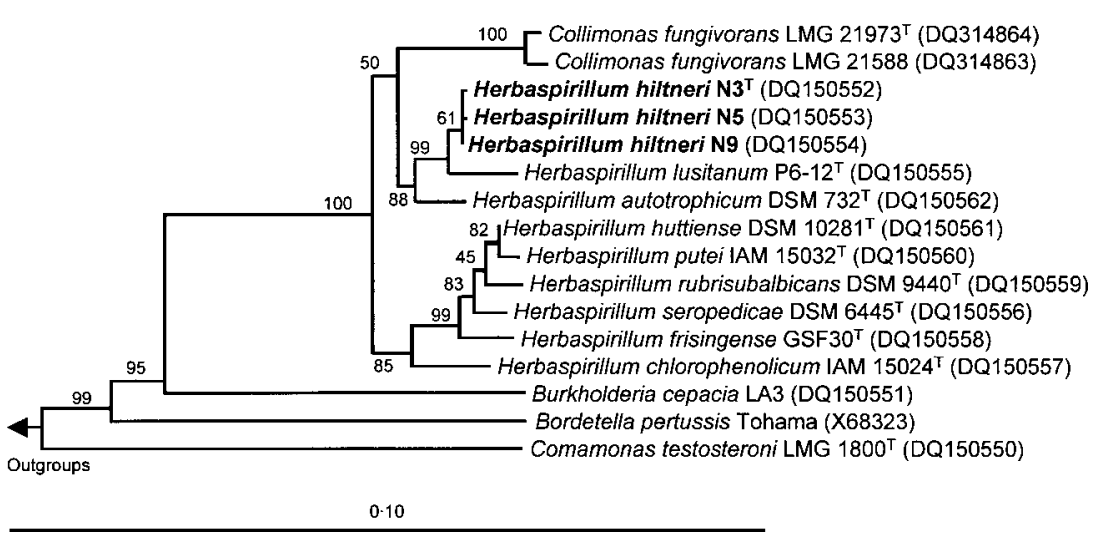

Fig. 2. Phylogenetic tree calculated with the neighbour-joining method based on 23S rRNA gene sequence data. Bootstrap values (percentages of 1000 resamplings) are given at branching points. NCBI accession numbers for sequence data are given in parentheses. The tree topology did not change significantly using maximum-likelihood and maximumparsimony methods. The tree includes all known members of the genus Herbaspirillum. Bar, $10 \%$ sequence divergence. isolated 11 strains from a bacterial freshwater community whose members had identical 16S rRNA gene sequences but which exhibited great genetic diversity and specific utilization of different carbon sources. Further examples exist in species of the genus Aeromonas (Martinez-Murcia et al., 1992) and Halobacillus (Amoozegar et al., 2003). There is no exact threshold for genus definition based on DNA-DNA hybridization values, but if the values between the individual Herbaspirillum species (10-45\%; Ding \& Yokota, 2004) are considered, the data presented unambiguously show that the isolates should be allocated to the genus Herbaspirillum. The values for DNA-DNA hybridization between isolate $\mathrm{N} 3^{\mathrm{T}}$ and the other Herbaspirillum species were as follows: H. autotrophicum DSM $732^{\mathrm{T}}, 32 \%$; H. rubrisubalbicans DSM $9440^{\mathrm{T}}, 30 \%$; H. huttiense DSM $10281^{\mathrm{T}}, 28 \%$; $H$. chlorophenolicum IAM $15024^{\mathrm{T}}, 25 \%$; H. seropedicae DSM $6445^{\mathrm{T}}, 20 \%$; H. frisingense $\mathrm{GSF} 30^{\mathrm{T}}, 17 \%$; and H. putei IAM $15032^{\mathrm{T}}, 14 \%$. Results were obtained from three independent measurements, with a standard deviation of $5 \%$.
Kirchhof et al. (2001) designed specific 16S rRNA genetargeted probes for the detection of all members of the genus Herbaspirillum that had validly published names at that time. The highly variable region at Escherichia coli positions 446-463 made differentiation possible down to the species level. Using the latest $16 \mathrm{~S}$ rRNA gene sequence data available from the NCBI database (National Center for Biotechnology Information, US National Library of Medicine, Bethesda, USA) and sequences obtained within the scope of this work, the same binding position could be used for the development of oligonucleotide probes that were specific for the newly described Herbaspirillum species. At the appropriate formamide concentration (given in Table 3), all probes allowed specific detection of their respective target organisms. In the case of probe Hhilu446, differentiation of H. lusitanum and the three isolates ( $3^{\mathrm{T}}$, N5 and $\left.\mathrm{N} 9\right)$ was not possible, because of their high levels of $16 \mathrm{~S}$ rRNA gene sequence similarity. The same is true for the pair $H$. huttiense and $H$. putei, which are both detected by

Table 3. Oligonucleotide probes for the specific detection of Herbaspirillum species by FISH

Binding positions in the 16S rRNA gene sequence of E. coli are according to Brosius et al. (1981). FA (\%) indicates the percentage of formamide in the hybridization buffer.

\begin{tabular}{|c|c|c|c|c|c|}
\hline Probe & Specificity & Binding position & Sequence $\left(5^{\prime}-3^{\prime}\right)$ & FA (\%) & Reference \\
\hline HERB69 & $\begin{array}{l}\text { H. seropedicae, H. rubrisubalbicans, } \\
\text { H. frisingense, H. chlorophenolicum, } \\
\text { H. huttiense, H. putei }\end{array}$ & $69-88$ & AGCAAGCTCCTATGCTGC & 20 & Kirchhof et al. (2001) \\
\hline Hahl998 & $\begin{array}{l}\text { H. autotrophicum, } \boldsymbol{H} \text {. hiltneri sp. nov., } \\
\text { H. lusitanum }\end{array}$ & $998-1015$ & CTCTTCAGGATTCCGTAC & 20 & This work \\
\hline Hrubri446 & $\begin{array}{l}\text { H. rubrisubalbicans (competitor for } \\
\text { Hhupu446) }\end{array}$ & $446-463$ & GCTACCACCGTTTCTTCC & 60 & Kirchhof et al. (2001) \\
\hline Hhupu446 & $\begin{array}{l}\text { H. huttiense, H. putei (with Hrubri446 } \\
\text { as competitor) }\end{array}$ & $446-463$ & GCTACTACCGTTTCTTCC & 35 & This work \\
\hline Hchloro446 & H. chlorophenolicum & $446-463$ & GCTGCAACCGTTTCTTCC & 50 & This work \\
\hline
\end{tabular}


Hhupu446. In addition, this probe has only one weakly destabilizing mismatch from the respective $H$. rubrisubalbicans target region. Therefore, in order to discriminate $H$. rubrisubalbicans, the application of an unlabelled oligonucleotide of Hrubri446 as a competitor is necessary when Hhupu446 is used.

The probe HERB69, which had been designed for the detection of the whole genus Herbaspirillum, did not hybridize with the species $H$. lusitanum, $H$. autotrophicum and the isolates $\mathrm{N} 3^{\mathrm{T}}, \mathrm{N} 5$ and $\mathrm{N} 9$. Thus, with the help of the probe-design tool of the ARB software package, the probe Hahl998 was designed, which binds to a 16S rRNA gene sequence region specific for these species. This probe can be used in an equimolar mixture together with HERB69 at the same formamide concentration to detect all members of the genus Herbaspirillum.

\section{Description of Herbaspirillum hiltneri sp. nov.}

Herbaspirillum hiltneri (hilt'ne.ri. N.L. gen. masc. n. hiltneri of Hiltner, in honour of Professor Lorenz Hiltner, who coined the rhizosphere concept in 1904).

Cells are Gram-negative, slightly curved rods that are motile due to (generally) two unipolar flagella. Circular, smooth, opaque and convex colonies are formed on NB agar after overnight growth at $30^{\circ} \mathrm{C}$. They are oxidase- and catalasepositive and the optimal growth temperature is $26-34^{\circ} \mathrm{C}$. The $\mathrm{pH}$ optimum lies between 6 and 8 . Single cells are $1 \cdot 6-2 \cdot 0 \mu \mathrm{m}$ in length and $0 \cdot 5-0 \cdot 6 \mu \mathrm{m}$ in diameter. A wide variety of sugars and alcohols, as well as fatty acids and some amino acids, are metabolized. In contrast to all other Herbaspirillum species, $H$. hiltneri sp. nov. is able to use L-phenylalanine as a carbon source. Disaccharides and trisaccharides are not metabolized. Shows $98.9 \% 23 \mathrm{~S}$ rRNA gene sequence similarity to its closest relative, $H$. lusitanum, but is not distinguishable from $H$. lusitanum on the basis of $16 \mathrm{~S}$ rRNA gene sequence data. Values for DNA-DNA hybridization to the other Herbaspirillum species range between 32 and $14 \%$; values for hybridization to isolates N5 and N9 exceed $95 \%$. DNA G + C content is 60.9-61.5 mol\%. Major fatty acids are $\mathrm{C}_{16: 1} \omega 7 c, \mathrm{C}_{16: 0}$ and $\mathrm{C}_{18: 1} \omega 7 c$.

The type strain, $\mathrm{N}^{\mathrm{T}}\left(=\mathrm{DSM} 17495^{\mathrm{T}}=\mathrm{LMG} 23131^{\mathrm{T}}\right)$, was isolated in close association with roots of Triticum aestivum. Its DNA G $+\mathrm{C}$ content is $60 \cdot 9 \mathrm{~mol} \%$.

\section{Acknowledgements}

We appreciate the skilful assistance of Daniela Weber and Angelika Schulz throughout this work, as well as the help of Helga Wehnes (GSF - Institute of Pathology) with the preparation of the electron micrographs. We are also indebted to Professor J. Igual for helpful advice and for providing $H$. lusitanum strains.

\section{References}

Amann, R. I., Krumholz, L. \& Stahl, D. A. (1990). Fluorescentoligonucleotide probing of whole cells for determinative and environmental studies in microbiology. J Bacteriol 172, 762-770.
Amann, R. I., Zarda, B., Stahl, D. A. \& Schleifer, K. H. (1992). Identification of individual prokaryotic cells by using enzyme-labeled, rRNA-targeted oligonucleotide probes. Appl Environ Microbiol 58, 3007-3011.

Amoozegar, M. A., Malekzadeh, F., Malik, K. A., Schumann, P. \& Sproer, C. (2003). Halobacillus karajensis sp. nov., a novel moderate halophile. Int J Syst Evol Microbiol 53, 1059-1063.

Bae, H. S., Lee, J. M., Kim, Y. B. \& Lee, S. T. (1996). Biodegradation of the mixtures of 4-chlorophenol and phenol by Comamonas testosteroni CPW301. Biodegradation 7, 463-469.

Baldani, J. I., Baldani, V. L. D., Seldin, L. \& Döbereiner, J. (1986). Characterization of Herbaspirillum seropedicae gen. nov., sp. nov., a root-associated nitrogen-fixing bacterium. Int J Syst Bacteriol 30, 86-93.

Baldani, J. I., Pot, B., Kirchhof, G. \& 8 other authors (1996). Emended description of Herbaspirillum; inclusion of [Pseudomonas] rubrisubalbicans, a mild plant pathogen, as Herbaspirillum rubrisubalbicans comb. nov.; and classification of a group of clinical isolates (EF group 1) as Herbaspirillum species 3. Int J Syst Bacteriol 46, 802-810.

Brosius, J., Dull, T. L., Sleeter, D. D. \& Noller, H. F. (1981). Gene organization of primary structure of a ribosomal operon from Escherichia coli. J Mol Biol 148, 107-127.

Cashion, P., Holder-Franklin, M. A., McCully, J. \& Franklin, M. (1977). A rapid method for the base ratio determination of bacterial DNA. Anal Biochem 81, 461-466.

de Boer, W., Leveau, J. H., Kowalchuk, G. A., Klein Gunnewiek, P. J., Abeln, E. C., Figge, M. J., Sjollema, K., Janse, J. D. \& van Veen, J. A. (2004). Collimonas fungivorans gen. nov., sp. nov., a chitinolytic soil bacterium with the ability to grow on living fungal hyphae. Int J Syst Evol Microbiol 54, 857-864.

De Ley, J., Cattoir, H. \& Reynaerts, A. (1970). The quantitative measurement of DNA hybridization from renaturation rates. Eur J Biochem 12, 133-142.

Ding, L. \& Yokota, A. (2004). Proposals of Curvibacter gracilis gen. nov., sp. nov. and Herbaspirillum putei sp. nov. for bacterial strains isolated from well water and reclassification of [Pseudomonas] huttiensis, [Pseudomonas] lanceolata, [Aquaspirillum] delicatum and [Aquaspirillum] autotrophicum as Herbaspirillum huttiense comb. nov., Curvibacter lanceolatus comb. nov., Curvibacter delicatus comb. nov. and Herbaspirillum autotrophicum comb. nov. Int J Syst Evol Microbiol 54, 2223-2230.

Döbereiner, J. (1995). Isolation and identification of aerobic nitrogen-fixing bacteria from soil and plants. In Methods in Applied Soil Microbiology and Biochemistry, pp. 134-141. Edited by K. Alef \& P. Nannipieri. London: Academic Press.

Döbereiner, J., Reis, V. M., Paula, M. A. \& Olivares, F. L. (1993). Endophytic diazotrophs in sugar cane, tuber plants and cereals. In New Horizons in Nitrogen Fixation, pp. 671-676. Edited by R. Palacios, J. Mora \& W. E. Newton. Dordrecht: Kluwer.

Elbeltagy, A., Nishioka, K., Sato, T., Suzuki, H., Ye, B., Hamada, T., Isawa, T., Mitsui, H. \& Minamisawa, K. (2001). Endophytic colonization and in planta nitrogen fixation by a Herbaspirillum sp. isolated from wild rice species. Appl Environ Microbiol 67, 5285-5293.

Escara, J. F. \& Hutton, J. R. (1980). Thermal stability and renaturation of DNA in dimethyl sulfoxide solutions: acceleration of the renaturation rate. Biopolymers 19, 1315-1327.

Felsenstein, J. (1993). PHYLIP (phylogeny inference package), version 3.5c. Distributed by the author. Department of Genome Sciences, University of Washington, Seattle, USA.

Fox, G. E., Wisotzkey, J. D. \& Jurtshuk, P., Jr (1992). How close is close: $16 \mathrm{~S}$ rRNA sequence identity may not be sufficient to guarantee species identity. Int J Syst Bacteriol 42, 166-170. 
Gattinger, A., Schloter, M. \& Munch, J. C. (2002). Phospholipid etherlipid and phospholipid fatty acid fingerprints in selected euryarchaeotal monocultures for taxonomic profiling. FEMS Microbiol Lett 213, 133-139.

Huß, V. A. R., Festl, H. \& Schleifer, K.-H. (1983). Studies on the spectrophotometric determination of DNA hybridization from renaturation rates. Syst Appl Microbiol 4, 184-192.

Im, W. T., Bae, H. S., Yokota, A. \& Lee, S. T. (2004). Herbaspirillum chlorophenolicum sp. nov., a 4-chlorophenol-degrading bacterium. Int J Syst Evol Microbiol 54, 851-855.

Jahnke, K. D. (1992). Basic computer program for evaluation of spectroscopic DNA renaturation data from GILFORD System 2600 spectrometer on a PC/XT/AT type personal computer. J Microbiol Methods 15, 61-73.

Jaspers, E. \& Overmann, J. (2004). Ecological significance of microdiversity: identical 16S rRNA gene sequences can be found in bacteria with highly divergent genomes and ecophysiologies. Appl Environ Microbiol 70, 4831-4839.

Kirchhof, G., Eckert, B., Stoffels, M., Baldani, J. I., Reis, V. M. \& Hartmann, A. (2001). Herbaspirillum frisingense sp. nov., a new nitrogen-fixing bacterial species that occurs in C4-fibre plants. Int J Syst Evol Microbiol 51, 157-168.

Kloos, K., Fesefeldt, A., Gliesche, C. G. \& Bothe, H. (1995). DNAprobing indicates the occurrence of denitrification and nitrogen fixation genes in Hyphomicrobium. Distribution of denitrifying and nitrogen fixing isolates of Hyphomicrobium in a sewage treatment plant. FEMS Microbiol Ecol 18, 205-213.

Ludwig, W., Strunk, O., Klugbauer, S., Klugbauer, N., Weizenegger, M., Neumaier, J., Bachleitner, M. \& Schleifer, K. H. (1998). Bacterial phylogeny based on comparative sequence analysis. Electrophoresis 19, 554-568.

Ludwig, W., Strunk, O., Westram, R. \& 29 other authors (2004). ARB: a software environment for sequence data. Nucleic Acids Res 32, 1363-1371.

Manz, W., Amann, R., Ludwig, W., Wagner, M. \& Schleifer, K.-H. (1992). Phylogenetic oligodeoxynucleotide probes for the major subclass of Proteobacteria: problems and solutions. Syst Appl Microbiol 15, 593-600.

Martinez-Murcia, A. J., Benlloch, S. \& Collins, M. D. (1992). Phylogenetic interrelationships of members of the genera Aeromonas and Plesiomonas as determined by $16 \mathrm{~S}$ ribosomal DNA sequencing: lack of congruence with results of DNA-DNA hybridizations. Int J Syst Bacteriol 42, 412-421.

Mesbah, M. \& Whitman, W. B. (1989). Measurement of deoxyguanosine/thymidine ratios in complex mixtures by high-performance liquid chromatography for determination of the mole percentage guanine + cytosine of DNA. J Chromatogr 479, 297-306.

Olivares, F. L., James, E. K., Baldani, J. I. \& Döbereiner, J. (1997). Infection of mottled stripe disease-susceptible and resistant sugar cane varieties by the endophytic diazotroph Herbaspirillum. New Phytol 135, 723-737.

Olsen, G. J., Matsuda, H., Hagström, R. \& Overbeek, R. (1994). fastDNAmL: a tool for construction of phylogenetic trees of DNA sequences using maximum likelihood. Comput Appl Biosci 10, 41-48.

Rossello-Mora, R. \& Amann, R. (2001). The species concept for prokaryotes. FEMS Microbiol Rev 25, 39-67.

Saitou, N. \& Nei, M. (1987). The neighbor-joining method: a new method for reconstructing phylogenetic trees. Mol Biol Evol 4, 406-425.

Schmid, M., Baldani, J. I. \& Hartmann, A. (2005). The Genus Herbaspirillum. In The Prokaryotes: an Evolving Electronic Resource for the Microbiological Community, 3rd edn, release 3.19. Edited by M. Dworkin. New York: Springer. http://link.springer-ny.com/link/ service/books/10125/

Stackebrandt, E. \& Goebel, B. M. (1994). Taxonomic note: a place for DNA-DNA reassociation and 16S rRNA sequence analysis in the present species definition in bacteriology. Int J Syst Bacteriol 44, 846-849.

Stoltzfus, J. R., So, R., Malarvithi, P. P., Ladha, J. K. \& de Bruijn, F. J. (1997). Isolation of endophytic bacteria from rice and assessment of their potential for supplying rice with biologically fixed nitrogen. Plant Soil 194, 25-36.

Strunk, O. \& Ludwig, W. (1997). ARB: a software environment for sequence data. http://www.arb-home.de/

Valverde, A., Velázquez, E., Gutiérrez, C., Cervantes, E., Ventosa, A. \& Igual, J.-M. (2003). Herbaspirillum lusitanum sp. nov., a novel nitrogen-fixing bacterium associated with root nodules of Phaseolus vulgaris. Int J Syst Evol Microbiol 53, 1979-1983.

Wayne, L. G., Brenner, D. J., Colwell, R. R. \& 9 other authors (1987). International Committee on Systematic Bacteriology. Report of the ad hoc committee on reconciliation of approaches to bacterial systematics. Int J Syst Bacteriol 37, 463-464.

Zehr, J. P. \& McReynolds, L. A. (1989). Use of degenerate oligonucleotides for amplification of the nifH gene from the marine cyanobacterium Trichodesmium thiebautii. Appl Environ Microbiol 55, 2522-2526.

Zelles, L. \& Bai, Q. Y. (1993). Fractionation of fatty acids derived from soil lipids by soil phase extraction and their quantitative analysis by GC-MS. Soil Biol Biochem 25, 130-134. 